\title{
Studentification and commodification of student lifestyle in Braamfontein, Johannesburg
}

\begin{abstract}
The process of studentification has emerged as a new form of neighbourhood change in the global North over the past 16 years and often situated within broader debates on gentrification. The growth of private student housing across cities globally has been linked to the increased neoliberalisation and massification of higher education and the lack of universities to keep up with the supply of student housing. Limited scholarship, however, exists on studentification in the global South. Notwithstanding that, in South Africa there has been growing recognition of the impact of studentification on urban environments. Despite some recognition in smaller cities, studentification has been neglected in large urban contexts. Using interviews with key informants and focus groups with students, this paper explores the impact of studentification in the urban neighbourhood of Braamfontein in Johannesburg. Over the past decade and a half there has been evidence of the concentration of student geographies and the commodification of student lifestyle in Braamfontein, Johannesburg.
\end{abstract}

Keywords: studentification, student lifestyle, commodification, Johannesburg

\section{Introduction}

Student geographies and their impact on the urban environment has become popular within debates on neighbourhood change over the past two decades (Smith \& Holt, 2007; Nakazawa, 2017). This coincides with the global massification of higher education, which has seen the exponential growth of student numbers since the 1980s. In 2002 the term 'studentification', was coined by Darren Smith who examined the impact of student housing on neighbourhood change in the United Kingdom. Studentification can be defined as the process of social, cultural, economic and physical changes that occur resulting from the influx of students, usually within privately rented accommodation in neighbourhoods close to higher education institutions (Smith, 2002; 2005). For many authors the process of studentification links with new ways in which capital is circulating through the urban environment, seeking new markets or lifestyles for commodification (Christie et al., 2002; Allison, 2006; Russo \& Tatjer, 2007; Holdsworth, 2009; Munro et al., 2009; Chatterton, 2010; Nakazawa, 2017). Overall, research on studentification aims to extend the conceptual boundaries of gentrification to include emerging processes of urban change.

The neoliberalisation and massification of higher education globally has seen universities becoming focused on profitability and many institutions have started to follow a 'businesslike model' or what Clark (1998) terms 'entrepreneurial university'. In search of increased profitability universities have embarked on outsourcing various student services, including housing (Clark, 1998; Maassen \& Cloete, 2004; Chatterton, 2010). Similar trends have been recorded in South Africa's higher education system. During the 1990s and after the demise of apartheid, the government embarked on a process of transforming and providing increased access to previously excluded and disadvantaged South Africans (Jansen, 2004; Akoojee \& 
Nkomo, 2007). Since then, higher education institutions across South Africa have experienced a rapid intake of students (Bunting, 2004; Akoojee \& Nkomo, 2007). Despite this growth in student numbers, university supplied accommodation could not keep up with the growing demand and the private sector has responded by providing student accommodation in the form of houses of multiple occupation (HMOs) and purpose-built student accommodation suppliers (PBSA) (Donaldson et al., 2014; Ackermann \& Visser, 2016).

Limited research, however, explores the impact of studentification and role of private suppliers of student accommodation on neighbourhood change within the South African context. The exception are case studies in Bloemfontein and Stellenbosch, where both the University of the Free State and Stellenbosch University were historically white Afrikaner universities. The process of studentification in Stellenbosch and Bloemfontein has largely affected former middle-class low-density residential suburbs (Benn, 2010; Donaldson et al., 2014; Ackermann \& Visser, 2016). On the larger metropolitan scale, the process of studentification is completely neglected in South Africa. It is against this backdrop that this paper will seek to investigate the economic and social impact of private student housing in the urban neighbourhood of Braamfontein in Johannesburg. An audit was conducted to document the number of student accommodation suppliers and other stakeholders in Braamfontein. The audit informed the sample of interviews. An interview was conducted with the biggest supplier of student accommodation in Braamfontein (and South Africa), namely South Point Properties. An interview with the Braamfontein Improvement District manager provides additional information on the impact of students on the area. Additionally, to gain a better understanding of students lived experiences in Braamfontein two focus groups were conducted - one group with students from the University of the Witwatersrand (Wits) and the second group of students from the University of Johannesburg (UJ). Furthermore, considerable time was spent at the study location and observations were documented through field notes which have aided in the analysis of this paper.

\section{Current debates on studentification}

Students have been noted to be agents of change in various geographical contexts, particularly in urban areas (Holton, 2016; Nakazawa, 2017). It is, however, only by the early 2000 s that the term studentification entered urban academic discourse. Studentification is often seen as a new form of gentrification and some authors argue for an extension of the conceptual meaning of gentrification to include emerging processes of neighbourhood change, such as studentification (Lees, 2003; Smith \& Butler, 2007; Smith \& Holt, 2007). The process of studentification is characterised by the in-migration of a student population that settles in privately rented accommodation in neighbourhoods close to higher education institutions (Smith, 2002, 2005). Students would either reside in privately rented houses of multiple occupation (HMOs) or in purpose-built student accommodation (PBSA) (Smith, 2002, 2005; Smith \& Holt, 2007). Since the early 2000s studentification has enjoyed growing research interest mostly within the context of the United Kingdom (see Smith, 2002, 2005; Smith \& Holt, 2007; Hubbard, 2008; Smith, 2008; Hubbard, 2009; Munro et al., 2009; Smith, 2009; Sage et al., 2012a, 2012b, 2013; Smith \& Hubbard, 2014; Smith et al., 2014; Holton, 2016). Limited research is available on the process of studentification beyond the UK, albeit there is growing recognition of this phenomenon elsewhere (Smith \& Holt, 2007; Nakazawa, 2017). Over the past decade there have been studies across Europe (Garmendia et al., 2012; Boersma et al., 2013; Grabkowska \& Frankowski, 2016; Fubula et al., 2017; Malet-Calvo, 
2017), Australia (Davison, 2009; Fincher \& Shaw, 2009) and the United States of America (Pickren, 2012; Laidley, 2014; Foote, 2017). The process of studentification has received very little attention in the global South, with exceptions of studies in China (He, 2015), Kenya (Fedha, et al., 2017) and growing research interest in South Africa (Donaldson et al., 2014; Ackermann \& Visser, 2016).

Within studentification literature a theme examined by several authors is the interconnections between gentrification and studentification. Smith's (2005) definition on studentification outlines four dimensions that closely link with the process of gentrification. First, studentification has an economic impact, which can lead to revalorisation and inflation of rent. Second, the social impact of studentification can lead to the displacement of former residents. Third, the rise of student culture and lifestyle can cause conflict and disruption within communities. Fourth, the physical environment - investment in student housing can lead to the initial upgrade of properties but followed by downgrading of the physical environment. The latter contradicts certain debates within gentrification, which highlights it as a process of upgrading the physical environment (Smith \& Holt, 2007).

It has been argued that studentification follows similar outcomes as gentrification. The inmigration of students into a neighbourhood could cause changes in the property market. If a rent-gap exist homeowners or developers can realise greater rental returns from a student submarket, which in turn can displace long term residents (Smith, 2009; Smith et al 2014). The concentration of students and their associated lifestyle can also cause conflict within communities and lead to the disruption, exclusion and displacement of 'well balanced' communities (Smith, 2009; Smith et al., 2014). Allen (2008) and Nakazawa (2017) agree that studentification can deepen segregation and concentration of social groups leading to geographies of exclusion within cities. Both processes of studentification and gentrification can stimulate social segregation, concentration of a particular population group and the widening of socio-spatial polarisation within cities that can lead to geographies of exclusion (see Smith, 2008, 2009; Munro et al., 2009; Boersma et al., 2013; Smith \& Hubbard, 2014; Nakazawa, 2017). Sage et al. (2013) argues that two types of displacement accompany studentification, these include exclusionary and socio-cultural displacement.

Early accounts of students acting as marginal gentrifiers have been documented by Ley (1996), Mills (1988) and Rose (1984). Ley (1996) states that youth culture is often viewed as the early recruits of gentrification. Spaces of higher education and student lifestyle are linked with acquiring cultural capital, which is essential for gentrification to occur (Ley, 2003). Thus Smith (2005) and Hubbard (2009) contends that students act as 'apprentice gentrifiers'. Smith and Holt (2007) argues that studentified spaces act as 'gentrification factories' - where students accumulate cultural capital and consume goods and services linked to middle-class aspirations. Hubbard (2009), however, argues that 'studenthood' or student lifestyle itself is being gentrified and that institutions and private investors are producing distinctive student districts or enclaves. Hubbard (2009) further posits that students are soon-to-be young professionals who are middle-class or are aspiring middle-class and seek an urban environment that caters to these aspirations.

Another important theme within the studentification scholarship is the cultural preferences or habitus of the student lifestyle, which affects neighbourhood change and can cause social and cultural conflict within the existing community (Smith \& Holt, 2007; Smith, 2009; Smith et al., 2014). The latter closely links with gentrification as student lifestyle can lead to exclusion of original residents. The concentration of student geographies and their lifestyle can 
contribute to conflict within communities and Chatterton (2000) contends that because of this potential conflict the geographies of students have become increasingly politicised and contested. Various authors point out that conflict between students and communities arise from some of the characteristics that are associated with a student lifestyle, one example includes partying and subsequent noise pollution (see Hubbard, 2008; Sage et al., 2012a, 2012b; Sage et al., 2013).

The commodification of student lifestyle is a further vibrant theme in extant literature and it is argued by Chatterton $(1999,2010)$ that it is linked to the neoliberalisation of higher education and student lifestyle. In the late 1990s Chatterton (1999) argued that the temporal and spatial framework of universities creates a student population who act as a distinctive group with a culture and lifestyle demanding specific sites of consumption. It is within this student space or habitus where student lifestyle and group associations are developed and maintained (Chatterton, 1999). It is this student space that have become increasingly commodified over the past two decades (Hubbard, 2008; Chatterton, 2010). For Chatterton (2010: 509) private student housing "represents new heights in the reformulation, upgrading and commodification of the student experience". Chatterton (2010) summarises what he believes is crucial for understanding the relationship between students and the urban environment. First, the creation of studentified areas is an extension of the neoliberliastion of student lifestyle. Second, the latter has stimulated the growth of a student urban service sector (which includes private student housing, retail and leisure services). Third, studentification as commodification has seen new investment opportunities and profit maximisation by property owners and developers and other retail and service providers that cater to a student market. Fourth, universities are not isolated from the urban context but do contribute to urban and neighbourhood change through processes of renewal and gentrification.

Chatterton (1999, 2010) Chatterton and Hollands (2002) and Hollands (2002) documented the growth of the student service sector, which includes private accommodation, retail and services. The student lifestyle has become a lucrative sector for corporate investors and seen as a stable niche market for rental income and the additional services students require (Hubbard, 2008). Hubbard (2009) draws attention to the economic opportunity of students who have increasingly gained purchasing power. Smith and Holt (2007) maintain that the 'manufacturing' of student areas are linked to capitalising on this niche student sub-market. Smith and Hubbard (2014) note that the production of 'student enclaves' and the commodification of student housing, is seen in the rise of purpose-built student accommodation and a plethora of retail and service offerings geared towards students (Smith \& Hubbard, 2014). Chatterton (2010: 511) summarises the growth of the student urban service sector as "whole swathes of city centres become dedicated to servicing students, especially in terms of retail, entertainment and leisure. Pubs, bars, nightclubs and fast-food and other retail outlets all pitch themselves at this lucrative, sizable and dependable consumer population". Part of the student service sector is the concept of what has been termed the night-time economy (Chatterton \& Hollands, 2002; Hollands, 2002). The night-time economy can be seen as urban playscapes where youthful night life is produced and consumed. The growth of the night-time economy poses certain challenges linked to public disorder and anti-social behaviour such as drunkenness, violence and vandalism (Chatterton \& Hollands, 2002; Hollands, 2002). Chatterton (2010) and Nakazawa (2017) focuses on sites of student consumption, linking it back to the conceptual issues surrounding gentrification as these sites of student consumption can lead to exclusion, segregation and conflict. Chatterton (2010) cautions that commodifying student lifestyle may exclude not only non-students, but different groups of students, along lines of social class and income. 


\section{Context of Braamfontein}

The inner-city area of Braamfontein is located north of Johannesburg's central business district. Before the 1950s it was largely characterised as a white working-class suburb. In 1946 the area was rezoned and gained full business rights, which stimulated commercial development from the 1950s. Braamfontein was considered as Johannesburg's first decentralised commercial node and seen as an extension of the central business district (Hart, 1969). The type of businesses that established themselves in Braamfontein were commercial office-based activities and had very little retail and residential concern. The construction of office space continued throughout the 1960s to the early 1980s (Hart, 1969; Beavon, 2004; Murray, 2011).

Johannesburg's central business district along with Braamfontein began to show early signs of stagnation and decline caused by widespread capital flight in the 1980s and 1990s (Rogerson, 1996). The latter was partly due to the crumbling apartheid regime and the rapid "greying" of many inner-city neighbourhoods - as well as continued decentralisation of businesses to commercial nodes such as Rosebank and Sandton, located further north of the city. It is, however, important to note that Braamfontein did not experience the same level of decline as the rest of the central business district. Despite this it failed to retain major corporates except for a few companies such as Liberty and Sappi. During the 1990s much of Braamfontein was characterised by low-end office activities who made use of the cheaper available office space (Rogerson \& Rogerson, 1995; Rogerson, 1996; Visser, 2002; Beavon, 2004; Murray, 2011; Todes, 2012).

During the mid to late 1990s the city of Johannesburg recognised the need for policy intervention to promote urban regeneration. It is, however, only by the early $2000 \mathrm{~s}$ with the establishment of the Johannesburg Development Agency (JDA) that some progress was made with investments in various urban renewal projects. A watershed for promoting property investment in the city was the introduction of the Urban Development Zone (UDZ) tax incentive in 2004. From the late 2000s onwards, the policy environment of the city became more favourable to support private property investors. Throughout the early 2000s the JDA upgraded various pavements, introduced public art and improved lighting in Braamfontein. The construction of the iconic Nelson Mandela Bridge linked Braamfontein with Newtown. In 2004 the Braamfontein Improvement District (BID) was established. The BID was one of the first legislated City Improvement Districts (CID) in Johannesburg where additional levies are charged on private property owners to fund the private urban management of the area (Beavon, 2004; Garner, 2011; Murray, 2011).

\section{Studentification in Braamfontein}

The growth of the student housing market in Braamfontein can be linked to the massification of higher education and the rapid growth of student numbers at both the University of the Witwatersrand (Wits) and the University of Johannesburg (UJ). Wits university is located on the North Western edge of Braamfontein (see Figure 1) and has doubled in its student numbers over the past two decades, from around 17000 students in the early 2000s to a capacity of over 36000 students by 2018 (Masinga, 2018). The University of Johannesburg has a student population of over 50000 students across its five campuses - the largest being the Auckland Park Kingsway campus, which is located about $3.5 \mathrm{~km}$ West from Braamfontein. The massive growth in student numbers and lack of university investment in 
providing on-campus housing has resulted in increased demand for private student housing. According to the Department of Higher Education (2011) there is massive demand for student accommodation. Braamfontein has emerged as an important district for student housing, capturing particularly the Wits student market, and to lesser extent students from the University of Johannesburg.

South Point Properties are the pioneers of student housing development in Braamfontein. Owned by the Public Investment Corporation, South Point Property Investments is the biggest supplier of student housing in Braamfontein (and in South Africa). The company was established in 2003 and initially acquired a few buildings which were redeveloped into student housing. South Point has grown their property portfolio to over 40 buildings nationally, the majority of which are concentrated in Braamfontein. An interview with a representative of South Point disclosed that in the early 2000s property in the area was relatively affordable and that the city provided incentives to lure private property developers to invest and upgrade the area. South Point recognised that there was a gap for private student housing with the increased student numbers at Wits. South Point invested in converting and retrofitting mid-rise office blocks into dormitory style student housing and residential apartments for graduates and young professionals. A representative at South Point explains that, "we were the pioneers of the industry, our approach is more than provision of accommodation, but to offer a student lifestyle". In 2018, South Point properties had 13 buildings in Braamfontein, which had been converted into student housing supplying accommodation for over 5000 students.

Student Digz is the second largest supplier of student housing in Braamfontein and is a division of International Housing Solutions (IHS), a global private equity investor, focusing on the affordable housing market in South Africa. Currently Student Digz has a property portfolio of six buildings in Braamfontein, housing, 1326 students in self-contained apartments. Amongst other smaller suppliers of student accommodation there is University Gate and J-One, which predominantly focus on luxury student accommodation. Overall, an audit conducted of student housing suppliers in Braamfontein revealed there is a population of over 6700 students living in Braamfontein. 


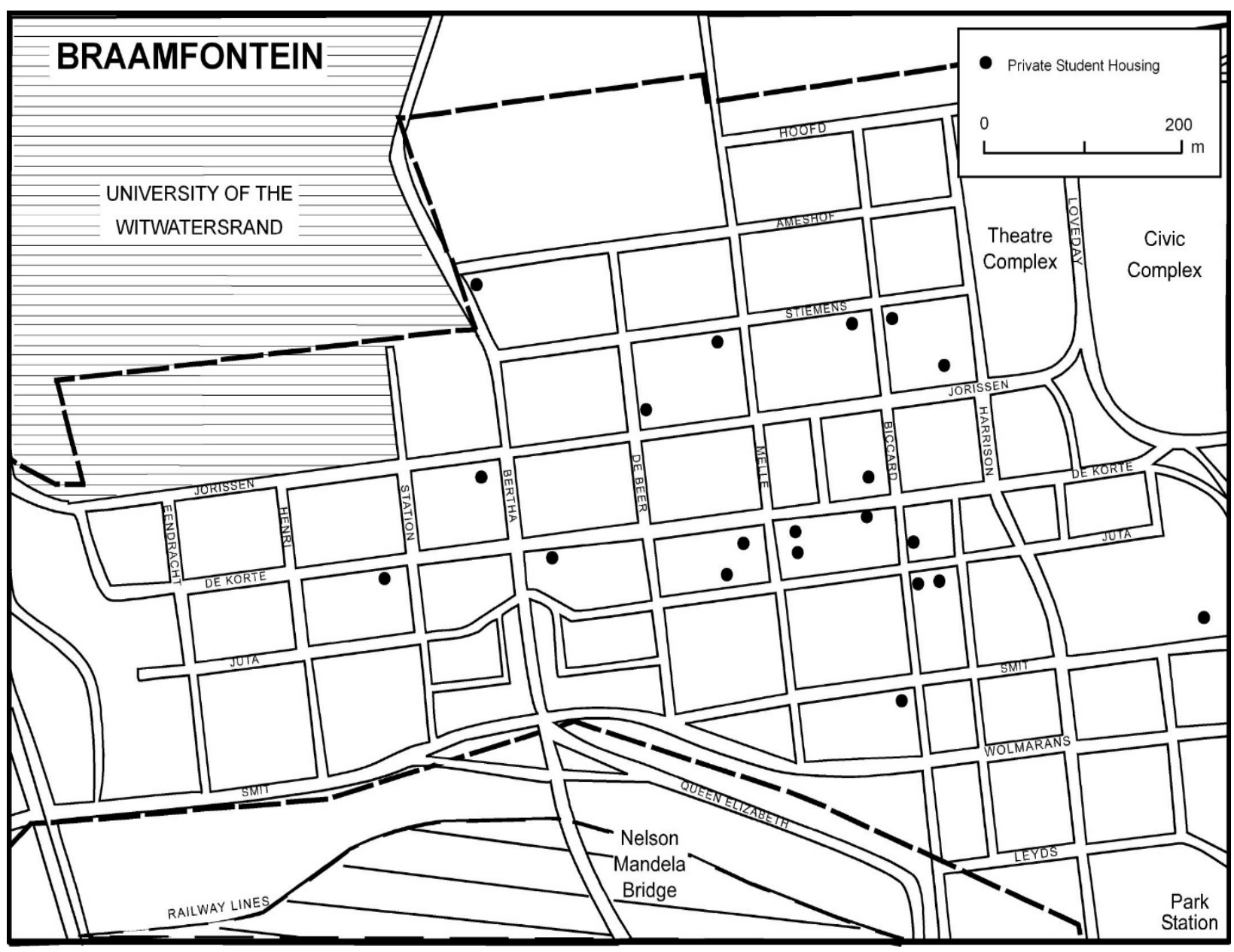

Figure 1: Private student accommodation in Braamfontein (illustration: James J. Gregory).

The various suppliers of student accommodation in Braamfontein has concentrated the student population and created a student district. The process of studentification over the past 15 years has changed the functional use of Braamfontein from a predominantly commercial node to a student district. Attention now shifts to understand the impact of a large student population on public space, retail and service offerings and the night-time economy in Braamfontein.

Braamfontein was developed as a commercial node and its infrastructure was never intended for a residential population. Due to the rise of a more permanent residential population the area is currently lacking public space for students and other residents. According to the BID manager the area has experienced a demographic shift with the introduction of a large student population. The BID in collaboration with Wits university and suppliers of student accommodation are seeking innovative ways to address the lack of and management of public space in Braamfontein. There is growing support from the university and private property owners in the area to view public space as an extension of private and institutional space. The influence of a small group of influential property owners and the subsequent establishment of the BID has led to the private management of public space in Braamfontein. The BID manager points out that the lack of public space in the area has contributed to various challenges. One of the biggest challenges are that students tend to congregate on pavements and social problems such as public drinking has emerged. 
The BID manager explains that "we have this influx of a student population that has nowhere to go. There is no public space for them, there is no communal space for them to go recreate. So those are some of the challenges that we now must find solutions to, if we don't want them on the street - where do we find those spaces for them and where do they go? Public space is currently a shortfall in the environment, but it is one of the challenges that we are dealing with." One example of public space intervention was the development of the Grove piazza. South Point properties demolished a building to create an open-air piazza, with various cafés, restaurants and a hotel facing the space. Despite creating much needed public space in Braamfontein, it can be argued that the creation of this public space has become privatised.

Apart from challenges linked to public space, the retail and service offerings in the area have also undergone change over the past 15 recent years. Despite their focus on student accommodation, South Point properties also has a significant concentration of retail and commercial space in Braamfontein. They have taken a curatorial approach to secure retail and commercial tenants that complements the student lifestyle. South Point's retail strategy is both inspirational and aspirational retail brands catering to a predominantly youth market. Examples include an array of trendy footwear and clothing stores, as well as coffee shops and restaurants. South Point's property portfolio in Braamfontein also consists of some commercial office space, which is predominantly focused on the NGO sector. They have recently completed the renovation of a commercial building focused on attracting NGOs.

It was reported by the interviewed representative of South Point Properties that, "five years ago, in [one] building there were two schools, a church, and small-scale entrepreneurs. If you go there now, there is Corruption Watch, Section 27, Swiss Art Council, Right-to-Know Campaign, etc. What this means is that the calibre of office workers has improved, which leads into an ecosystem, they are the kind of tenants that will come out and have a cappuccino and have lunch as they do have disposable income and more purchasing power, they could support an Apple store for example".

It can be argued that an element of retail and commercial gentrification has occurred in Braamfontein as many buildings have been renovated and higher rental rates can be achieved. Mid-level and higher-end retailers are attracted to the area as the student population and higher-end office workers have more purchasing power, thus displacing lower-end commercial and retail activities. Most of the higher-end retail brands are clustered along Juta and Melle streets (see Figure 1). Despite the growth of higher-end retail brands in Braamfontein there is still a large number of mid-range and lower-end activities. Various national chains and fast food outlets are located along Jorissen and De Korte streets, which are the main thoroughfares through Braamfontein. There are also examples of low-end and informal retailing scattered throughout the district, and these are mostly convenience stores or tuck shops and hairdressers. Many of the low-end offerings are clustered along Biccard street, one of the main thoroughfares linking Braamfontein with Johannesburg's central business district (see Figure 1).

The influx of a student population has stimulated the growth of the entertainment and nighttime economy in Braamfontein. Over the past 15 years different markets have emerged that are attracted to Braamfontein's entertainment facilities. There are curated spaces such as the Neighbourgoods market (a food and design market) and other trendy bars, shops and restaurants that mostly draws visitors on weekends (see Naicker \& Rogerson, 2017). These visitors include middle-class suburbanites, creatives and tourists. The students do frequent 
bars and restaurants but also support more spontaneous parties that often spill out onto the streets. Additionally, there are also visitors that are attracted to the area to socialise with students. Various bars and night clubs have opened, and the trend of public drinking has grown significantly over the past few years. South Point and the BID are aware of the social problems that have emerged because of the growth of the night time economy and various issues surrounding public drinking, fighting and substance abuse have been noted. Of great concern is the emergence of 'car-bars' or 'boot-parties', where people drink alcohol and party from their cars parked on the streets of Braamfontein.

The BID manager explains that, "the student population has produced a spontaneous night life that have predominantly spilled out onto the streets, the boot bar culture has become a very extensive and common character [on] the streets of Braamfontein. Although it's great to have this spontaneous night life it is also a challenge, the spaces are then not safe, we don't want fights or people to get hurt or young female students being unaware of the environment they are in and vulnerable within the space"

South Point states that the risk involved with unregulated public drinking is that it has the potential to destabilise other commercial and retailing offerings in the area, as it becomes a threat to security. The BID is aware of this and trying to manage the various social problems that have emerged as a result of the night-time economy. The BID manager, however, does highlight a lack of commitment from the Johannesburg Metropolitan Police Department (JMPD) as an obstacle in dealing with issues surrounding public drinking and safety. It is evident that investment in student housing in Braamfontein has produced a distinctive student district. The introduction of a student population into an area that was developed as a commercial node has created challenges in dealing with public space management, stimulated the growth of retail, services and entertainment facilities that cater to a student market. It has, however, also stimulated the growth of the night-time economy, contributing to socially disruptive problems such as public drinking posing a risk to safety in the area. Inferences drawn from two focus groups explores the students lived experiences in Braamfontein.

\section{Student lifestyle in Braamfontein}

The majority of the students that participated in the focus groups were black South African students, most of whom were the first in their families to attend university. Majority of the students indicated that they do not live near Wits or UJ and need to seek accommodation closer to the institutions. The students are attracted to Braamfontein because of the proximity it offers to Wits university. They also felt that Braamfontein is safer compared to downtown Johannesburg and it offers access to an attractive student lifestyle. Many of the students state that there is an array of student services, retail and entertainment facilities within walking distance from accommodation suppliers and campus.

The affordability of higher education in South Africa has become a contentious issue, which reached a critical point with the eruption of the Fees Must Fall protests in 2015 and 2016. Students from Wits were at the forefront of this movement and the protest action spilled out onto the streets of Braamfontein (Booysen, 2016). The focus group with Wits students revealed that many students face financial difficulties. A lot of students that attend Wits are self-funded which puts a lot of pressure on families to fund tuition, especially for poor and working-class students. Students that indicated that they have bursaries noted that most 
bursaries do not fully cover tuition fees, cost of accommodation and other living expenses, thus many students experience a financial shortfall.

One Wits student explains; "I mean the R4500 per month (R - South African Rand) that South Point charges, means you must be paying around R45 000 per year and then if you must pay another R60 000 in [tuition] fees... bursaries don't really give over a R100 000 per year, especially in undergrad. So, you will have to top-up somehow, somewhere. And that basically is just you sleeping and going to class, it does not include what you wear, eat and drink, your devices...”.

In terms of affordability, UJ students have a different perspective. UJ's tuition fees are much lower compared to Wits and many students receive funding from schemes such as the National Student Financial Aid Scheme (NSFAS). Coupled with lower tuition fees and government funding, UJ students do have more spending power for accommodation. Many UJ students receive NSFAS which is enough to cover both tuition fees and accommodation costs and they do not encounter the same excessive financial shortfall as many students from Wits do. The majority of UJ students in the focus group felt that Braamfontein is relatively affordable. As one UJ student recounts "It's affordable as a NSFAS student. So, we can stay at accredited buildings and they don't charge us anything. So, we just sign up the lease and once you are a NSFAS student, automatically they will fund you to stay there".

It is important to note that the National Student Financial Aid Scheme (NSFAS) has played a key role in the setting the price for the cost of private accommodation across the country and they largely control the rates of the student housing market. The NSFAS is a government organisation that provides financial aid to students from poor and working-class families. The scheme pays a set fee of around R3000 per month for students in shared rooms. The majority of accredited accommodation suppliers offers shared rooms at the rate as set up by the NSFAS scheme. Suppliers of accommodation receives payment directly from NSFAS and often are inspected by universities and NSFAS, thus their pricing needs to adhere to the strict guidelines as set out by the scheme. Students who prefer single rooms (at around R4000 per month), however, must top up and pay an additional R1000 or more through privately funded means.

The affordability for students stretches beyond the cost of accommodation but also the cost of retail and services that are on offer in Braamfontein. The majority of the students do feel that there is a diverse mix of retail and services in the area that cater to different income levels. When asked about some of the higher-end retail offerings in the area that sell expensive clothing and footwear the students felt that these brands are overpriced and do not fit with a student budget, but they do recognise that this is what the youth market wants. One student notes, "I think some of those shops are way too expensive, they need to understand that we are students. You need to wait for a 'blesser' to buy you those things". Another student indicates that, "it's unethical of them to have those kind of shops in a student district". Many students feel that these higher-end brands contribute to the student lifestyle or culture of Braamfontein, but that it is not necessarily affordable for many students. One student points out, "yes, brands are using student lifestyle and culture to make money, that is their aim. They know as students we are attracted to their products. They are selling a lifestyle".

The majority of students in both focus groups pointed out that a distinctive sub-culture or student lifestyle has emerged in Braamfontein. Students who conform to this particular lifestyle are referred to as "Braam kids". This particular sub-culture is focused on a certain 
lifestyle, achieving social status through the way they dress, the type of music they listen to and the places they hang out. Most of the students in both groups indicated that there is social and peer pressure to conform to the "Braam kids" lifestyle. The introduction of inspirational and aspirational lifestyle brands in the area is influencing student culture. As one student pointed out, "these brands add to that aspiring lifestyle. The brands come here, knowing there is a market and that students dress in a certain style". The social pressures of conforming to a lifestyle and achieving social status has contributed to social problems such as the "blesser phenomenon", where many wealthier older men visit Braamfontein and some young female students resort to relationships with them for financial reward.

One student explains, "these first-year students come here, and when they come here, there is already a way of living that already exists. More often than not these students don't have enough money. There is a lot of peer pressure, you have to do something outside the class and find a way to have fun or whatever and many don't really have the means to do that. The means to buy themselves nice clothes or fit in with the aesthetics of the city so they then turn to those blessers and it's something that happens quite a lot". The role of social media in promoting aspirational brands and achieving social status is very common amongst students. Social media applications such as Instagram and Facebook are constantly used by students to portray an aspirational lifestyle through the consumption of various lifestyle brands. One student points out that "there are that many girls who are desperate to fit in with the whole 'slay queen' image. I think social media also has a lot to do with it. In South Africa right now there is this trend to be more materialistic, to be more popular... Instagram life. So, there are these social pressures from social media to be cool and look nice or whatever, so they don't have the means to do it. So they turn to blessers".

Another important aspect of student lifestyle is entertainment and partying. Students living in Braamfontein feel that there is a lot of freedom to party. Some students do point out issues of alcohol and substance abuse, which tends to spill out onto the streets. Most students agree that street parties and car boot parties have become popular, as it is more affordable than going to bars or clubs. One student recalls, "on the street people simply blast music from their cars and drink from their cars". Another student notes "there is a lot of public drinking and boot bars. Most people don't even get into these clubs, they just park their cars there and drink. Most student accommodation suppliers don't allow alcohol on the premises and this pushes it out onto the streets. There are a lot of foreigners as well that sell alcohol on the street." Students have noted issues surrounding public drinking have led to crime, fights and vulnerability of drunk students, particularly female students with increased risk of sexual assault.

\section{Discussion and conclusion}

Overall, there is growing research interest on the impact of studentification in urban South Africa. The majority of research focus, however, has been on the impact of private student housing (mostly HMOs) in residential areas in Bloemfontein and Stellenbosch (see Benn, 2010; Ackermann \& Visser, 2016; Donaldson et al., 2014). This paper adds to debates on studentification in South Africa and offers new insight on the impact of studentification in a larger urban context in South Africa.

Over the past 15 years re-investment in student housing has transformed Braamfontein as a student district and produced concentrated student geographies. The production of 
Braamfontein as a student district stretches beyond the supply of accommodation, but includes retail, services and entertainment - producing a distinctive area for student lifestyle consumption. It can be argued that with the introduction of a large student population in Braamfontein the area has shifted from a stagnating commercial node to a growing student district, which has stimulated investment and contributed to urban renewal. This links with international studies that draw linkages between studentification and urban regeneration, particularly with PBSA developments in brownfields in inner-city areas (Macintyre, 2003; Nakazawa, 2017; Smith et al., 2014). Furthermore, the case of Braamfontein contributes to the limited international literature where commercial office space has been retrofitted into student housing. Similar cases have been investigated in Australia and New Zealand (Collins, 2010; Fincher \& Costello, 2005; Tsutsumi \& O'Connor, 2011). The retrofitting of commercial office space into student housing is not unique to Johannesburg, but there is evidence of this in city centres across South Africa. More research is needed to explore the impact of this phenomenon on declining commercial nodes and its potential for urban regeneration in South Africa.

Chatterton $(1999,2010)$ argues that the development of student housing and the curation of retail and services to capture the student market represents the ongoing commodification of the student experience. It can be argued that the neoliberalisation of higher education and the private provision of student accommodation and other student services contributes to the increased commodification of student lifestyle. There is some evidence of this in Braamfontein where the creation of a student district through the supply of accommodation and retail and services catered to a student market has attracted private sector investment and is seen as a lucrative sub-market to invest in. Like many other aspects of urban life, the private sector can realise profit from student lifestyle.

In Braamfontein, South Point Properties have recognised that the student population are aspiring middle- class, and they have positioned brands in the area that meet those aspirations. There is, however, as many students have pointed out the issue of actual affordability of the student market. The latter links with Chatterton and Hollands (2002) who have noted in their research that some groups of students will be excluded based on income and the rising cost of the student lifestyle. This is of concern in South Africa where the majority of students come from poor and working-class families, thus feeling extreme pressures to conform to an aspiring middle-class lifestyle that is being promoted. The use of inspirational or aspirational branding is not new, and often used in marketing brands to youth culture (Saviolo \& Maraszza, 2012). This raises the question about how ethical this type of brand positioning is in Braamfontein for a student market who do not necessarily have the means to buy these brands, who are highly impressionable and under peer pressure to conform to a particular student lifestyle. Many students in this research revealed that they feel extreme social pressures to conform to the student lifestyle that has been created and evolved in Braamfontein over the past few years. The latter has contributed to various social problems such as the blesser phenomenon, impacting particularly on young female students in exploitative sexual relationships. The growth of a concentrated student population in Braamfontein has also stimulated the growth of a night-time economy. The spontaneous nightlife that spills out onto the streets have been noted to be a destabalising factor in the district. More research is needed to explore the interconnections between studentification and the night-time economy in urban South Africa.

Despite the growth of higher-end lifestyle brands in certain parts of Braamfontein, the area still offers a mix of retail and service offerings for different income levels and can be 
considered a diverse space, bringing together a mix of cultures, races and classes. It can be argued that this form racial and class intersection is much needed in urban South Africa with a tainted history of racial segregation and post-apartheid class-based segregation. As one property developer notes; "what I think is interesting about these new spaces is it is figuratively and literally where Sandton can meet Soweto". There is, however, the risk that with continued investment and concentration of student geographies the diversity of the area will be lost. Retail and commercial gentrification might make the space less diverse and a space for student and aspiring middle-class consumption. Hubbard (2009) asserts that the creation of concentrated student geographies can lead to the same effects as gentrification, there is the social concentration of one group, which contributes to social segregation and the subsequent displacement of residents or other economic activities that do not fit into 'studenthood'. There are elements of commercial gentrification noted in Braamfontein, where retail and services catering to a student sub-market are becoming increasingly concentrated. Smith (2005) and Hubbard (2009) calls students living in commodified student districts 'apprentice gentrifiers' or a 'gentrification factory'. Braamfontein could be labeled as an incubator for apprentice gentrifiers, where the presence of certain brands and the student lifestyle that has emerged is cultivating a taste for middle-class consumption. Nakazawa (2017) cautions against this and states that the concentration of student geographies can lead to geographies of exclusion in cities.

James J. Gregory, Department of Geography, Environmental Management \& Energy Studies, University of Johannesburg, Johannesburg, South Africa (jamesg@uj.ac.za)

Jayne M. Rogerson, School of Tourism \& Hospitality, College of Business and Economics,, University of Johannesburg, Johannesburg, South Africa (jayner@uj.ac.za)

\section{Acknowledgement}

Many thanks to D. Greenberg for cartographic assistance.

\section{References}

Ackermann, A. \& Visser, G. (2016) Studentification in Bloemfontein, South Africa. Bulletin of Geography. Socio-economic Series, 31, pp. 7-17. DOI: 10.1515/bog-2016-0001

Akoojee, S. \& Nkomo, M. (2007) Access and quality in South African higher education: The twin challenges of transformation. South African Journal of Higher Education, 21(3), pp. 385-399.

Allen, C. (2008) Housing market renewal and social class. London, Routledge. DOI: 10.4324/9780203932742

Allison, J. (2006) Over-educated, over-exuberant and over here? The impact of students on cities. Planning, Practice \& Research, 21(1), pp. 79-94. DOI: 10.1080/02697450600901541

Beavon, K. S. O. (2004) Johannesburg: The making and shaping of the city. Pretoria, Unisa Press.

Benn, J. D. (2010) Studentifikasie in Stellenbosch. Master's thesis. Stellenbosch University, Stellenbosch.

Boersma, K., Langen, H. \& Smets, P. (2013) Paradoxes of Studentification: Social mix versus gentrification in a disadvantaged neighborhood in Amsterdam East. The Open Urban Studies Journal, 6(1), pp. 40-49. DOI: $10.2174 / 1874942901306010040$

Booysen, S. (2016) Fees Must Fall: Student Revolt, Decolonisation and Governance in South Africa. Johannesburg, Wits University Press. DOI: 10.18772/22016109858

Bunting, I. (2004) The higher education landscape under apartheid. In: Cloete, N., Maassen, P., Fehnel, R., Moja, T. Perold, H. \&Gibbon, T. (eds.) Transformation in Higher Education-Global pressures and local realities in South Africa, pp. 35-53. Dordrecht, Kluwer Academic Publishers.

Chatterton, P. (1999) University students and city centres - the formation of exclusive geographies. The case of Bristol, UK. Geoforum, 30, pp. 117-133. DOI: 10.1016/S0016-7185(98)00028-1 
Chatterton, P. (2000) The cultural role of universities in the community: revisiting the university-community debate. Environment and Planning A, 32, pp. 165-181. DOI: 10.1068/a3243

Chatterton, P. (2010) The student city: an ongoing story of neoliberalism, gentrification, and commodification. Environment and Planning A, 42(3), pp. 509-514. DOI: 10.1068/a42293

Chatterton, P. \& Hollands, R. (2002) Theorising urban playscapes: producing, regulating and consuming youthful nightlife city spaces. Urban studies, 39(1), pp. 95-116. DOI: 10.1080/00420980220099096

Christie, H., Munro, M. \& Rettig, H. (2002) Accommodating students. Journal of Youth Studies, 5(2), pp. 209235. DOI: $10.1080 / 13676260220134458$

Clark, B. R. (1998) The entrepreneurial university: demand and response. Tertiary Education and Management, 4(1), pp. 5-16. DOI: 10.1080/13583883.1998.9966941

Davison, G. (2009) Carlton and the campus: the university and the gentrification of inner Melbourne 195875. Urban Policy and Research, 27(3), pp. 253-264. DOI: 10.1080/08111140903118365

Department of Higher Education and Training (2011) Report on the ministerial committee for the review of the provision of student housing at South African universities. Available at: http://www.justice.gov.za/commissions/FeesHET/docs/2011-Report-MinisterialCommitteeReviewStudentHousingSAUniversities.pdf (accessed 13 July 2017).

Donaldson, R., Campbel, M., Benn, J. \& de Jager, A. (2014) Reshaping urban space through studentification in two South African urban centres. Urbani Izziv, 25(Supplement), pp. 176-188. DOI: 10.5379/urbaniizziv-en-2014-25-supplement-013

Fabula, S., Boros, L., Kovács, Z., Horváth, D. \& Pál, V. (2017) Studentification, diversity and social cohesion in post-socialist Budapest. Hungarian Geographical Bulletin, 66(2), pp. 157-173.

DOI: 10.15201/hungeobull.66.2.5

Fedha, N., Murenga, H. \& Bor, E. (2017) Effects of Off Campus Students’ Activities on Well-Being of Community Neighbouring Egerton University, Nakuru County, Kenya. International Journal of Innovative Research and Development, 6(5), pp. 47-53. DOI: 10.24940/ijird/2017/v6/i5/MAY17021

Fincher, R. \& Shaw, K. (2009) The unintended segregation of transnational students in central Melbourne. Environment and Planning A, 41(8), pp. 1884-1902. DOI: 10.1068/a41126

Foote, N. S. (2017) Beyond studentification in United States College Towns: Neighborhood change in the knowledge nodes, 1980-2010. Environment and Planning A, 49(6), pp. 1341-1360. DOI: $10.1177 / 0308518 X 17698962$

Garmendia, M., Coronado, J. M. \& Ureña, J. M. (2012) University students sharing flats: When studentification becomes vertical. Urban Studies, 49(12), pp. 2651-2668. DOI: 10.1177/0042098011428176

Garner, G. (2011) Johannesburg ten ahead: a decade of inner city regeneration. Johannesburg, Double G Media.

Grabkowska, M. \& Frankowski, J. (2016) 'Close to the city centre, close to the university'. Are there symptoms of studentification in Gdańsk, Poland? Bulletin of Geography. Socio-economic Series, 32(32), pp. $73-83$.

Hart, G. H. T. (1969) The structure of Braamfontein: its nodes and surfaces. South African Geographical Journal, 51(1), pp. 73-87. DOI: 10.1080/03736245.1969.10559450

He, S. (2015) Consuming urban living in 'villages in the city': Studentification in Guangzhou, China. Urban Studies, 52(15), pp. 2849-2873. DOI: 10.1177/0042098014543703

Holdsworth, C. (2009) 'Going away to uni': mobility, modernity, and independence of English higher education students. Environment and Planning A, 41(8), pp. 1849-1864. DOI: 10.1068/a41177

Hollands, R. (2002) Divisions in the dark: youth cultures, transitions and segmented consumption spaces in the night-time economy. Journal of Youth Studies, 5(2), pp. 153-171. DOI: 10.1080/13676260220134421

Holton, M. (2016) Living together in student accommodation: performances, boundaries and homemaking. Area, 48(1), pp. 57-63. DOI: 10.1111/area.12226

Hubbard, P. (2008) Regulating the social impacts of studentification: a Loughborough case study. Environment and Planning A, 40(2), pp. 323-341. DOI: 10.1068/a396

Hubbard, P. (2009) Geographies of studentification and purpose-built student accommodation: leading separate lives? Environment and planning A, 41(8), pp. 1903-1923. DOI: 10.1068/a4149

Jansen, J. D. (2004) Changes and continuities in South Africa's higher education system, 1994-2004. In: Chisholm, L. (ed.) Changing class: Education and social change in post-apartheid South Africa, pp. 293-314. London, Zed books.

Laidley, T. M. (2014) The privatization of college housing: Poverty, affordability, and the US public university. Housing Policy Debate, 24(4), pp. 751-768. DOI: 10.1080/10511482.2013.875053

Lees, L. (2003) Super-gentrification: The case of Brooklyn heights, New York City. Urban Studies, 40(12), pp. 2487-2509. DOI: 10.1080/0042098032000136174

Lees, L. (2008) Gentrification and social mixing: towards an inclusive urban renaissance? Urban Studies, 45(12), pp. 2449-2470. DOI: 10.1177/0042098008097099 
Ley, D. (2003) Artists, aestheticisation and the field of gentrification. Urban studies, 40(12), pp. 2527-2544. DOI: $10.1080 / 0042098032000136192$

Ley, D. (1996) The new middle class and the remaking of the central city. Oxford, Oxford University Press.

Maassen, P. \& Cloete, N. (2004) Global reform trends in higher education. In: Cloete, N., Maassen, P., Fehnel, R., Moja, T., Perold, H. \& Gibbon, T. (eds.) Transformation in Higher Education-Global pressures and local realities in South Africa, pp.7-35. Dordrecht, Kluwer Academic Publishers.

Macintyre, C. (2003) New models of student housing and their impact on local communities. Journal of Higher Education Policy and Management, 25(2), pp. 109-118. DOI: 10.1080/1360080032000122598

Malet Calvo, D. (2017) Understanding international students beyond studentification: A new class of transnational urban consumers. The example of Erasmus students in Lisbon (Portugal). Urban Studies, pp. $1-17$.

Masinga, L. (2018) No new applications accepted for 2018 says Wits. Available at: https://citizen.co.za/news/south-africa/1772894/no-new-applications-accepted-for-2018-says-wits/ (accessed 4 May 2018).

Mills, C. A. (1988) "Life on the upslope": the postmodern landscape of gentrification. Environment and planning D: Society and space, 6(2), pp. 169-190. DOI: 10.1068/d060169

Munro, M., Turok, I. \& Livingston, M. (2009) Students in cities: a preliminary analysis of their patterns and effects. Environment and Planning A, 41(8), pp. 1805-1825. DOI: 10.1068/a41133

Murray, M. J. (2011) City of extremes: The spatial politics of Johannesburg. Durham, Duke University Press. DOI: $10.1215 / 9780822391814$

Nakazawa, T. (2017) Expanding the scope of studentification studies. Geography Compass, 11(1), pp. 1-13. DOI: $10.1111 / \mathrm{gec} 3.12300$

Pickren, G. (2012) "Where Can I Build My Student Housing?" The Politics of Studentification in Athens-Clarke County, Georgia. South-Eastern Geographer, 52(2), pp. 113-130. DOI: 10.1353/sgo.2012.0019

Rogerson, J. (1996) The geography of property in inner-city Johannesburg. GeoJournal, 39(1), pp. 73-79. DOI: 10.1007/BF00174931

Rogerson, C. M. \& Rogerson, J. M. (1995) The decline of manufacturing in inner-city Johannesburg 19801994. Urban Forum, 6(1), pp. 17-42. DOI: 10.1007/BF03036692

Rose, D. (1984) Rethinking gentrification: beyond the uneven development of Marxist urban theory. Environment and planning D: Society and Space, 2(1), pp. 47-74. DOI: 10.1068/d020047

Russo, A. P. \& Tatjer, L. C. (2007) From citadels of education to Cartier Latins (and back?): The changing landscapes of student populations in European cities. Geography Compass, 1(5), pp. 1160-1189. DOI: $10.1111 /$ j.1749-8198.2007.00056.x

Sage, J., Smith, D. \& Hubbard, P. (2012a) The diverse geographies of studentification: Living alongside people not like us. Housing Studies, 27(8), pp. 1057-1078. DOI: 10.1080/02673037.2012.728570

Sage, J., Smith, D. \& Hubbard, P. (2012b) The rapidity of studentification and population change: there goes the (student) hood. Population, Space and Place, 18(5), pp. 597-613. DOI: 10.1002/psp.690

Sage, J., Smith, D. \& Hubbard, P. (2013) New-build studentification: A panacea for balanced communities? Urban Studies, 50(13), pp. 2623-2641. DOI: 10.1177/0042098013477694

Saviolo, S. \& Marazza, A. (2012). Lifestyle brands: A guide to aspirational marketing. London, Palgrave Macmillan. DOI: $10.1057 / 9781137285935.0008$

Smith, D. (2002) Patterns and processes of studentification in Leeds. The Regional Review, 12(1), pp. 15-16.

Smith D. (2005) Studentification: the gentrification factory. In: Atkinson, R. \& Bridge, G. (eds.) Gentrification in a global context: The new urban colonialism, pp. 73-90. London, Routledge. DOI: 10.4324/9780203392089_chapter_5

Smith, D. (2008) The politics of studentification and (un)balanced urban populations: lessons for gentrification and sustainable communities? Urban Studies, 45(12), pp. 2541-2564. DOI: 10.1177/0042098008097108

Smith, D. (2009) Guest editorial: Student geographies. Environment and Planning A, 41(8), pp. 1795-1804. DOI: $10.1068 / \mathrm{a} 42257$

Smith, D. \& Butler, T. (2007) Conceptualising the socio-spatial diversity of gentrification: 'to boldly go' into contemporary gentrified spaces, the 'final frontier'?. Environment and Planning A, 39, pp. 2-9. DOI: $10.1068 / \mathrm{a} 39322$

Smith, D. \& Holt, L. (2007) Studentification and 'apprentice' gentrifiers within Britain's provincial towns and cities: extending the meaning of gentrification. Environment and Planning A, 39(1), pp. 142-161. DOI: $10.1068 / \mathrm{a} 38476$

Smith, D. \& Hubbard, P. (2014) The segregation of educated youth and dynamic geographies of studentification. Area, 46(1), pp. 92-100. DOI: 10.1111/area.12054

Smith, D., Sage, J. \& Balsdon, S. (2014) The geographies of studentification: 'here, there and everywhere'?. Geography, 99(3), pp. 116-127. 
Todes, A. (2012) Urban growth and strategic spatial planning in Johannesburg, South Africa. Cities, 29(3), pp. 158-165. DOI: 10.1016/j.cities.2011.08.004

Visser, G. (2002) Gentrification and South African cities: towards a research agenda. Cities, 19(6), pp. 419-423. DOI: 10.1016/S0264-2751(02)00072-0 